\title{
IDENTIFIKASI SUNGAI BAWAH PERMUKAAN PADA DATA RESISTIVITAS 2D KONFIGURASI DIPOLE- DIPOLE DI DESA GEDOMPOL, KABUPATEN PACITAN
}

\author{
Ayi Syaeful Bahri, Muthi'ul Padlilah*, Amien Widodo, Anik Hilyah, Singgih Purwanto, Putry Vibry \\ Hardyani, Christopher Salim \\ Departemen Teknik Geofisika, Fakultas Teknik Sipil Perencanaan dan Kebumian, Institut Teknologi Sepuluh Nopember \\ *Penulis Korespondensi : muthiulfadlilah23@gmail.com
}

\begin{abstract}
Abstrak. Kawasan karst Pacitan tersusun oleh batuan karbonat yang mudah larut akibat adanya proses karstifikasi. Batuan karbonat ini memiliki banyak rongga percelahan yang menjadikan drainase bawah permukaan lebih berkembang dalam bentuk aliran sungai bawah permukaan. Tujuan dari penelitian ini adalah untuk mengidentifikasi sungai bawah permukaan dari data resistivitas 2D. Penelitian dilakukan di Desa Gedompol, Kecamatan Donorojo, Kabupaten Pacitan menggunakan metode geolistrik resistivitas 2D konfigurasi Dipole-Dipole. Akuisisi data dilakukan pada 3 lokasi berbeda sehingga dihasilkan 3 lintasan yaitu Dipole-1, Dipole-2, dan Dipole-3 yang memiliki panjang lintasan 230 meter. Penerapan konfigurasi DipoleDipole pada penelitian ini dilakukan untuk dapat mengetahui nilai resistivitas yang dihasilkan dari penampang bawah permukaan dengan target yang lebih dalam daripada konfigurasi lain, serta mampu memberdakan nilai resistivitas batuan secara kontras. Hasil penelitian menunjukkan bahwa anomali sungai bawah permukaan teridentifikasi pada penampang 2D di kedalaman 5 - 35 meter dengan nilai resistivitas berkisar antara 1,26 - 12,4 $\Omega \mathrm{m}$. Anomali ini berbentuk rongga akibat pengaruh sistem perkembangan sungai bawah permukaan yang termasuk ke dalam zona vadose. Pada zona ini, air menginfiltrasi vertikal ke dalam tanah melalui luweng dan ketika memasuki zona jenuh, air akan bergerak ke arah horizontal mengikuti celah yang semakin lama semakin melebar hingga membentuk saluran sungai bawah permukaan atau kantung air.
\end{abstract}

Kata Kunci: karst, konfigurasi Dipole-Dipole, sungai bawah permukaan

\begin{abstract}
The Pacitan karst area is composed of carbonate rocks that soluble easily due to the karstification process. This carbonate rock has many crevices that make subsurface drainage more developed and formed subsurface river flows. The purpose of this research is to identify subsurface rivers from 2D resistivity data. The research was conducted in Gedompol Village, Donorojo District, Pacitan Regency using the 2D resistivity geoelectrical method with Dipole-Dipole configuration. Data acquisition was carried out at 3 different locations resulting in 3 lines, namely Dipole-1, Dipole-2, and Dipole-3 with track length of 230 meters. The application of the Dipole-Dipole configuration in this research was carried out to determine the resistivity value generated from the subsurface section with a deeper target than other configurations, and to be able to distinguish rock resistivity values in contrast. The results showed that the subsurface river anomaly was identified in a 2D cross-section at depth of $5-35$ meters with resistivity values ranging from $1.26-12.4$ $\Omega . m$. This anomaly is in the form of a cavity due to the influence of the subsurface river development system which is included in the vadose zone. In this zone, water infiltrates vertically into the soil through the hole and whilst it enter the saturated zone, the water will pass in a horizontal direction following the distance which is increasingly widening to form a subsurface river channel or water pocket.
\end{abstract}

Keywords: karst, Dipole-Dipole configuration, subsurface river

\section{PENDAHULUAN}

Kawasan karst Pacitan memiliki bentang alam yang khas dan tersusun oleh batuan yang mudah larut terutama batuan karbonat yang memiliki porositas sekunder (Ford dan Williams, 2013). Kawasan karst ini termasuk ke dalam Zona Pegunungan Selatan dengan Subzona Gunung Sewu. Formasi yang menyusun daerah penelitian yaitu Formasi Wonosari (Gambar 1) yang terdiri dari batugamping terumbu, batugamping berlapis, batugamping pasiran, batugamping mengeping, dan napal. Karst ini terbentuk akibat adanya proses karstifikasi yang terjadi pada kawasan dengan bentukan morfologi baik di permukaan (eksokarst) seperti bukit-bukit tunggal dan lekuk-lekuk lembah (dolina), serta morfologi di bawah permukaan (endokarst) seperti sistem perguaan dan aliran sungai bawah tanah (Samodra, 2003). Karakteristik batuan karbonat yang memiliki rongga percelahan serta mudah terlarut di dalam air menyebabkan 
drainase permukaan atau keberadaan sungai permukaan tidak berkembang, namun didominasi oleh adanya drainase yang terdapat di bawah permukaan (sungai bawah permukaan). Hal ini dikarenakan air mengisi pori-pori batuan tersebut sehingga memiliki sifat dinamis (Adji dan Haryono, 2004).

Berkembangnya aliran sungai bawah permukaan ini ditemukan di Desa Gedompol, Kecamatan Donorejo, Kabupaten Pacitan. Menurut Andriyani dkk. (2010), kawasan tersebut merupakan kawasan kekeringan yang krisis air. Lokasi daerah penelitian berada di kawasan perbukitan yang memilki puncak-puncak membulat berukuran kecil (conical hill) sehingga menjadikan target anomali yang ditemukan berada pada posisi yang sangat dalam. Hal ini ditunjukkan oleh hasil penelitian dimana anomali sungai bawah permukaan berada pada kedalaman 21,8 - 62,3 meter (Andriyani dkk., 2010). Selain itu, berdasarkan informasi yang disampaikan oleh organisasi PSS (Pacitan Speleology Society), Desa Gedompol menjadi desa yang paling parah mengalami kekeringan di Kecamatan Donorojo. Berdasarkan hal itu, perlu dilakukan penelitian untuk dapat menemukan dugaan sumber air berupa sungai bawah permukaan. Metode geofisika yang dapat digunakan untuk menemukan dugaan sungai bawah permukaan tersebut adalah metode geolistrik resistivitas 2D.

Pengukuran metode geolistrik dilakukan menggunakan konfigurasi Dipole-Dipole. Hal ini dikarenakan konfigurasi ini dapat mengidentifikasi nilai resistivitas batuan secara kontras dan memiliki resolusi yang tinggi secara horizontal. Selain itu target kedalaman yang dihasilkan dari penampang bawah permukaan cenderung lebih dalam jika dibandingkan dengan konfigurasi lain (Ebraheem dkk., 2012). Nilai range resistivitas yang dihasilkan oleh konfigurasi ini juga lebih lebar dan bervariasi daripada konfigurasi Wenner-Schlumberger sehingga dapat memetakan lapisan gamping di dasar yang memiliki nilai resistivitas rendah dengan baik serta dapat menjangkau kedalaman yang sangat dalam (Putra dan Hermawan, 2016). Dengan demikian, diharapkan metode ini dapat menunjukkan target anomali sungai bawah permukaan secara akurat.

\section{Sungai Bawah Permukaan}

Sistem hidrologi yang terdapat pada kawasan karst memiliki perbedaan dengan kawasan selain karst. Pada kawasan karst, air mengalir melalui retakan berupa celah pada gua yang membentuk aliran konduit (melalui suatu saluran). Sementara itu pada kawasan selain karst, air bergerak melalui poripori yang terdapat di antara butiran batuan dan mengalir secara intergranular (melalui ruang antar butiran) (Samodra, 2003). Batuan karbonat yang mendominasi kawasan karst memiliki karakteristik berupa adanya rongga percelahan yang mudah terlarut di dalam air. Hal ini menyebabkan drainase permukaan atau keberadaan sungai permukaan tidak berkembang, namun didominasi oleh adanya

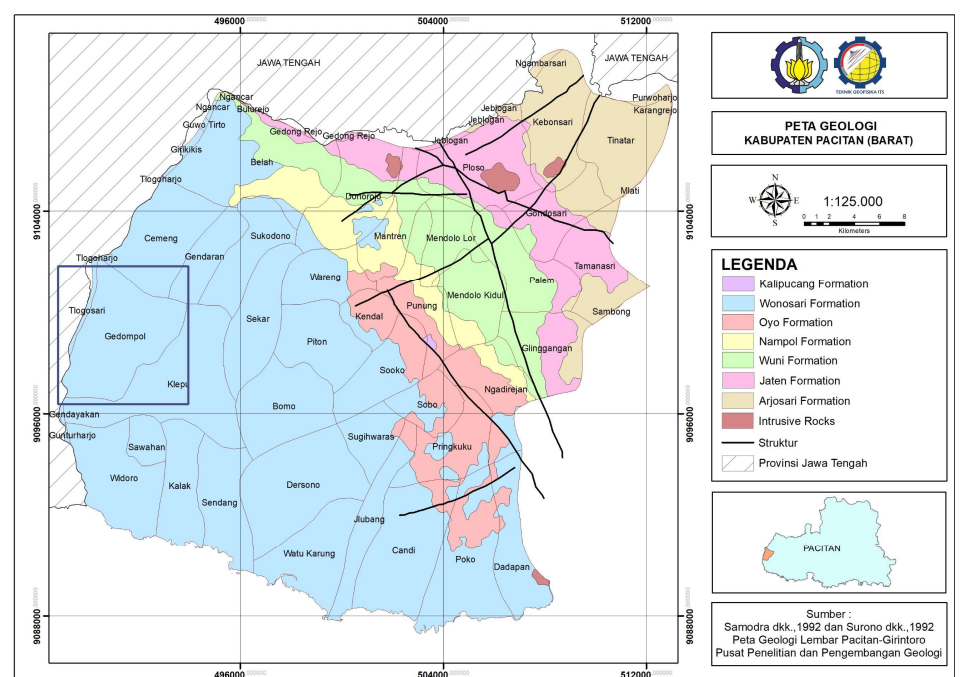

Gambar 1. Peta geologi daerah penelitian (Samodra dkk., 1992; Surono dkk., 1992) 
drainase yang terdapat di bawah permukaan (sungai bawah permukaan). Hidrologi karst bawah permukaan ini disebut juga dengan airtanah karst dimana air mengisi pori-pori batuan tersebut sehingga memiliki sifat dinamis (Adji dan Haryono, 2004).

Daerah penelitian termasuk ke dalam kawasan unit hidrogeologi sub-sistem Donorojo-Pringkuku. Sub-sistem Donorojo-Pringkuku menunjukkan aliran airtanah ke selatan secara umum yang dikendalikan oleh sistem sesar atau rekahan dengan pola struktur berarah NE - SW (Timur Laut - Barat Daya) yang merupakan sesar geser sinistral dan NW - E (Barat Laut - Tenggara) yang merupakan sesar geser dekstral (Bemmelen, 1949; Haryono, 2011). Selain itu hasil penelitian lain menunjukkan hal yang sama bahwa sesar-sesar yang terbentuk pada wilayah penelitian merupakan sesar normal dan mendatar hasil deformasi tektonik dengan arah Timur Laut Barat Daya serta sesar mendatar dengan arah Barat Laut - Tenggara (Aliyan dkk., 2020). Penelitian lain menyebutkan, aliran sungai bawah permukaan yang ditemukan di Kedung Banteng (Donorojo) memiliki arah NW - SE (Barat Laut - Tenggara), sedangkan di Dersono (Pringkuku) memiliki arah NE-SW (Timur Laut - Barat Daya) (Bahri dkk., 2021; Chemistra dkk., 2018). Semakin ke arah selatan, airtanah secara bertahap semakin memasuki kawasan inti karstifikasi. Secara umum batuan dasar yaitu batugamping pada sub-sistem ini lebih dangkal daripada batuan dasar pada zona Gunung Sewu bagian tengah. Fenomena ini mengakibatkan muka airtanah menjadi lebih dangkal yang ditandai oleh adanya mata air yang mengaliri sungai permukaan. Imbuhan alogenik pada sub-sistem ini juga dapat diidentifikasi sebagian besar berupa sungai bawah permukaan (Haryono, 2011).

\section{Metode Geolistrik Resistivitas}

Survei geolistrik ini memiliki tujuan untuk memperoleh gambaran distribusi nilai resistivitas bawah permukaan yang memanfaatkan sifat kelistrikan dari medium di bawah permukaan (Yuspancana dkk., 2019). Prinsip metode geolistrik ini didasarkan pada Hukum Ohm, di mana besarnya nilai potensial $(\mathrm{V})$ merupakan hasil kali dari besarnya arus
(I) dengan resistansi (R). Maka, untuk mendapatkan nilai $\mathrm{R}$ dalam Hukum $\mathrm{Ohm}$ adalah sebagai berikut (Telford dkk., 1990) :

$$
V=I \cdot R
$$

Lapisan bawah permukaan bumi yang diasumsikan bersifat homogen isotropis menyebabkan arus yang dihasilkan membentuk bidang equipotential yang berbentuk setengah bola $(2 \pi r 2)$ dengan garis aliran arus medan listrik berada pada arah radial (Telford dkk., 1990). Apabila arus listrik dilakukan injeksi melalui dua titik, akan terjadi distribusi potensial yang ditunjukkan oleh Gambar 2 .

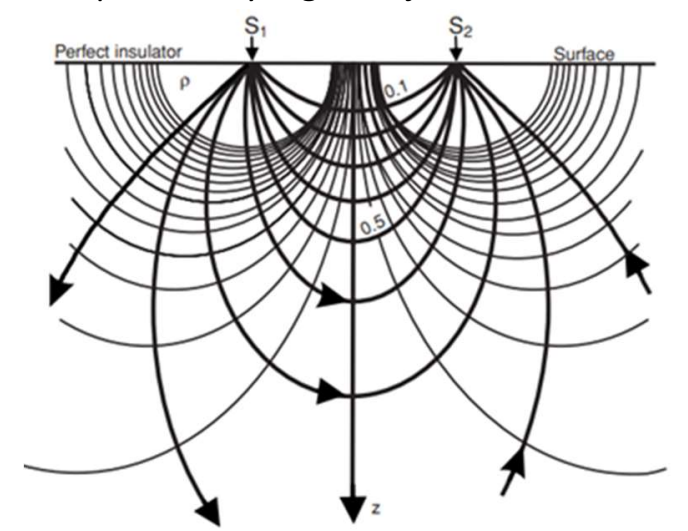

Gambar 2. Arus dan bidang equipotential yang telah dilakukan injeksi (Reynolds, 2011)

Distribusi besarnya nilai arus dan nilai beda potensial yang terukur akan menghasilkan nilai resistivitas yang didapatkan dari persamaan berikut :

$$
\rho=R . k
$$

dimana $\rho$ adalah nilai resistivitas, $R$ adalah resistansi, dan $\mathrm{k}$ adalah faktor geometri. Faktor geometri yang dihasilkan dari konfigurasi Dipole-Dipole pada penelitian ini ditunjukkan pada gambar 3 sebagai berikut :

$$
\begin{aligned}
& k=\pi a(n)(n+1)(n+2) \\
& \text { Dipole-dipole }
\end{aligned}
$$

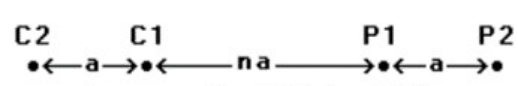

$$
\begin{aligned}
& k=x n(n+1)(n+2) a
\end{aligned}
$$

Gambar 3. Jarak antar elektroda pada konfigurasi Dipole-Dipole (Loke, 2001)

Selain itu, resistivitas batuan berkaitan dengan konduktivitas batuan dimana hal tersebut menunjukkan kemampuan batuan dalam menghantarkan arus listrik. Nilai resistivitas tinggi menunjukkan bahwa batuan tersebut sukar dalam 
menghantarkan listrik dan sebaliknya (Prameswari dkk., 2012). Interpretasi nilai resistivitas yang digunakan secara umum didasarkan pada beberapa acuan pada Gambar 4 dan Tabel 1 di bawah ini :

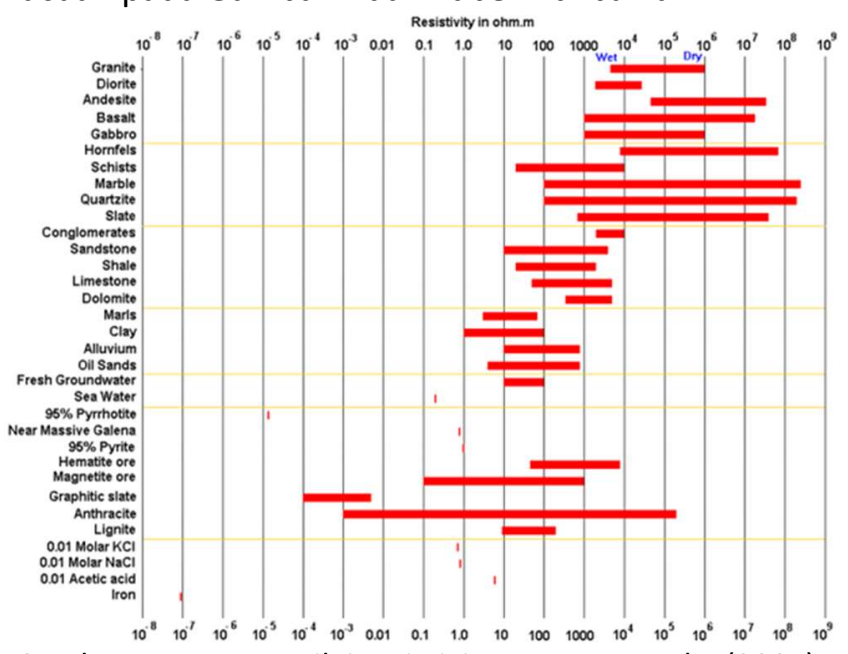

Gambar 4. Rentang nilai resistivitas menurut Loke (2001)

Tabel 1. Referensi distribusi nilai resistivitas menurut Telford dkk. (1990)

\begin{tabular}{cc}
\hline Jenis Mineral/Batuan & Nilai Resistivitas \\
\hline Meteoric waters & $30-10^{3} \Omega . \mathrm{m}$ \\
Surface water (ign. Rocks) & $0,1-3 \times 10^{3} \Omega . \mathrm{m}$ \\
Surface water (sediments) & $10-100 \Omega . \mathrm{m}$ \\
Soil waters & $100 \Omega . \mathrm{m}$ \\
Natural water (ign. Rocks) & $0,5-150 \Omega . \mathrm{m}$ \\
Natural waters (sediments) & $1-100 \Omega . \mathrm{m}$ \\
Sea water & $0,2 \Omega . \mathrm{m}$ \\
Sandstones & $1-6,4 \times 10^{8} \Omega . \mathrm{m}$ \\
Limestone & $50-10^{7} \Omega . \mathrm{m}$ \\
Dolomite & $3,5 \times 10^{2}-5 \times 10^{3}$ \\
& $\Omega . \mathrm{m}$ \\
Unconsolidated wet clay & $20 \Omega . \mathrm{m}$ \\
Marls & $3-70 \Omega . \mathrm{m}$ \\
Clays & $1-100 \Omega . \mathrm{m}$ \\
Oil sands & $4-800 \Omega . \mathrm{m}$ \\
\hline
\end{tabular}

Sementara itu, interpretasi nilai resistivitas batuan yang digunakan pada analisis ini didasarkan pada penelitian yang dilakukan di kawasan karst oleh Agus (2005) dalam Naufaldi (2018) serta Tobing (2020), dengan membagi litologi menjadi lima bagian seperti yang ditunjukkan pada Tabel 2 (Kuswanto, 2005; Naufaldi, 2018; Tobing, 2020).

Tabel 2. Referensi distribusi nilai resistivitas di daerah penelitian (Kuswanto, 2005; Naufaldi, 2018; Tobing, 2020)

\begin{tabular}{cc}
\hline Jenis Anomali & Nilai Resistivitas \\
\hline Top soil & $1-20 \Omega . \mathrm{m}$ \\
\hline
\end{tabular}

\begin{tabular}{cc}
\hline Batuan karbonat terumbu & $20-250 \Omega \cdot \mathrm{m}$ \\
Goa penuh air & $1-20 \Omega \cdot \mathrm{m}$ \\
Goa kosong & $>1000 \Omega \cdot \mathrm{m}$ \\
Goa setengah kosong & $50-100 \Omega \cdot \mathrm{m}$ \\
\hline
\end{tabular}

Berdasarkan referensi rentang nilai resistivitas di atas, daerah penelitian yang termasuk ke dalam Formasi Wonosari secara umum didominasi oleh batuan karbonat terumbu. Target anomali yang berupa sungai bawah permukaan dikategorikan ke dalam goa penuh air karena memiliki bentuk rongga yang terisi oleh anomali dengan nilai resistivitas rendah. Jika dibandingkan dengan marls (napal), nilai resistivitas yang dihasilkan oleh goa penuh air tersebut relatif lebih kecil sehingga anomali resistivitas rendah diidentifikasi sebagai target anomali sungai bawah permukaan yang berada pada rentang $1-20 \Omega . m$.

\section{METODOLOGI}

Penelitian ini dilakukan di Desa Gedompol, Kecamatan Donorojo, Kabupaten Pacitan, Jawa Timur. Diagram alir penelitian ditunjukkan seperti pada Gambar 5.

\section{Tahapan Pra-Akuisisi Data}

Penelitian dilakukan dengan studi literatur terlebih dahulu yang meliputi pencarian referensi teori seperti data geologi serta penelitian terdahulu. Kemudian melalui studi literatur ini akan dirumuskan bagaimana penelitian dilakukan semestinya. Setelah itu kemudian dilakukan survey pendahuluan untuk mengamati kondisi medan yang akan dilakukan akuisisi. Hasil dari survey pendahuluan berupa desain akuisisi penelitian dimana penentuan lokasi penelitian didasarkan pada kondisi lapangan yang berada pada dolina atau cekungan tertutup yang biasanya dimanfaaatkan sebagai lahan perkebunan serta memiliki elevasi yang relatif rendah. Rancangan lintasan yang akan dilakukan pengukuran adalah 3 lintasan yang berada di lokasi berbeda seperti pada Gambar 6 dan 7. 


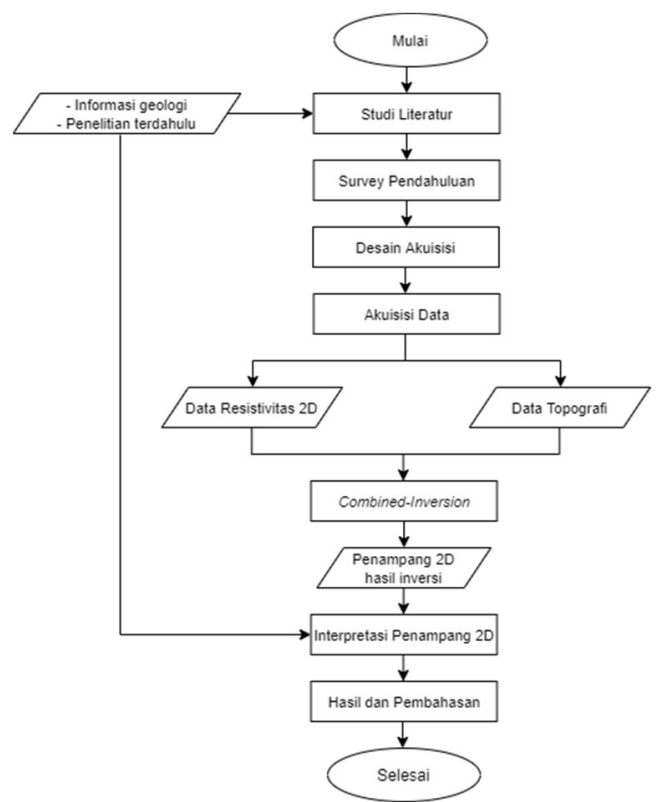

Gambar 5. Diagram alir penelitian

Desain akuisisi tersebut dibuat atas pertimbangan kondisi dari setiap lintasan sebagai berikut :
Lintasan Dipole-1 (Gambar 8) terbentang sepanjang 230 meter dengan arah lintasan Tenggara - Barat Laut. Kondisi daerah lintasan Dipole-1 berada di kebun warga dengan topografi datar hanya sepanjang \pm 90 meter sedangkan topografi lainnya relatif curam. Di sekitar lintasan pengukuran terdapat pohon trembesi. Lintasan pengukuran berada cukup jauh dengan manifestasi Luweng Tirisan yang memiliki jarak \pm 600 meter. Akuisisi data dilakukan pada tanggal 27 Mei 2021.

Lintasan Dipole-2 (Gambar 9) terbentang sepanjang 230 meter dengan arah lintasan Barat Laut - Tenggara. Kondisi daerah lintasan Dipole-2 berada di kebun warga dengan topografi relatif datar pada meter 0-110 sedangkan topografi pada meter 120230 cukup curam. Di sekitar lintasan pengukuran terdapat pohon trembesi dan pohon bambu. Lintasan pengukuran berada dekat dengan manifestasi berupa luweng (Luweng Gedompol)

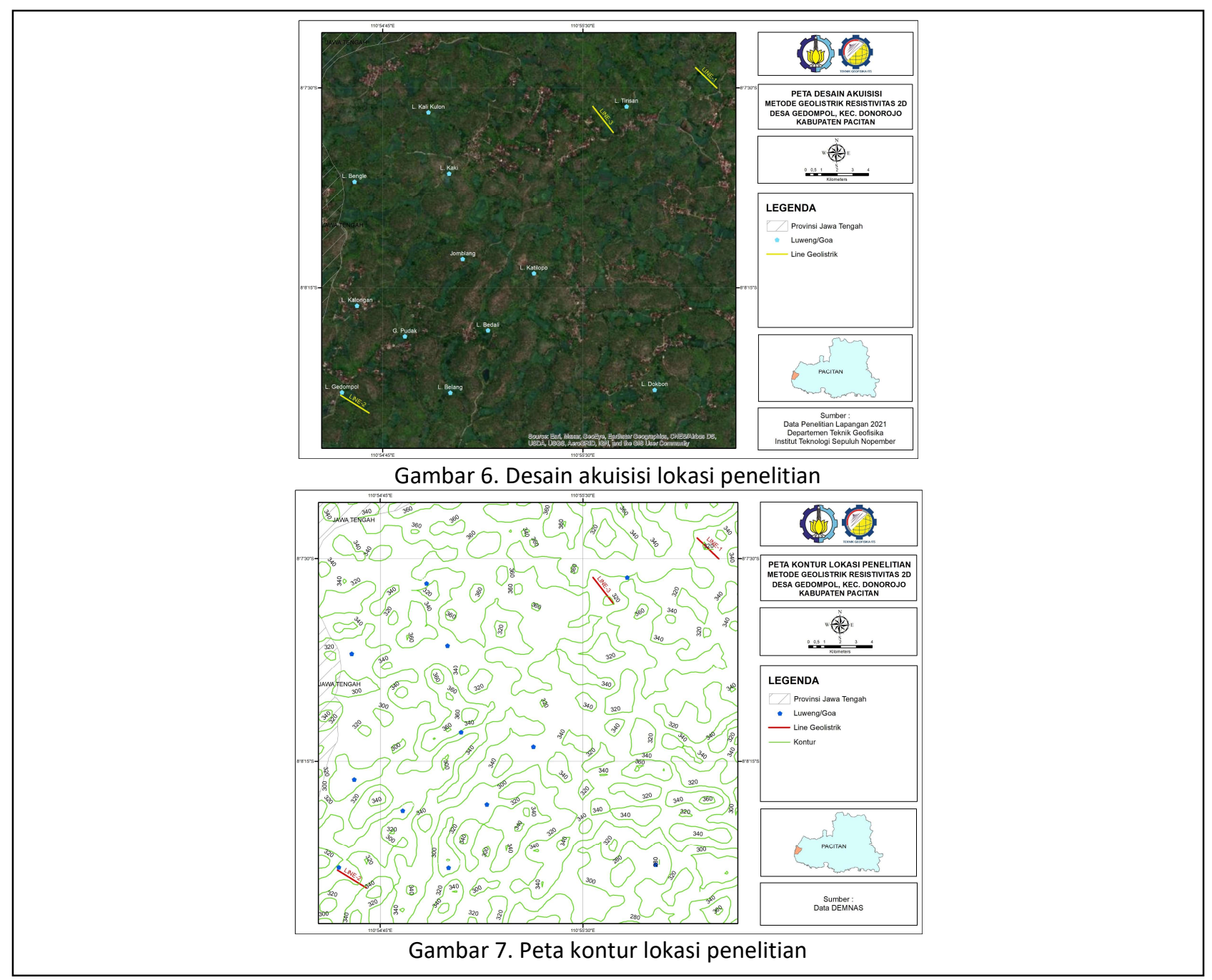

Artikel diterima 28 September 2021, Revisi 27 November 2021 Online 30 Desember 2021 
yaitu sekitar 20 meter dari titik awal pengukuran yang kondisinya kering atau tidak terdapat air. Akuisisi data dilakukan pada tanggal 24 Mei 2021.

Lintasan Dipole-3 (Gambar 10) terbentang sepanjang 230 meter dengan arah lintasan Tenggara - Barat Laut. Kondisi daerah lintasan Dipole-3 berada di kebun warga dengan topografi relatif datar pada meter 0-120 sedangkan topografi pada meter 130230 cukup curam. Di sekitar lintasan pengukuran terdapat pohon trembesi. Lintasan pengukuran berada dekat dengan manifestasi Luweng Tirisan yang memiliki jarak sekitar 200 meter. Akuisisi data dilakukan pada tanggal 26 Mei 2021.

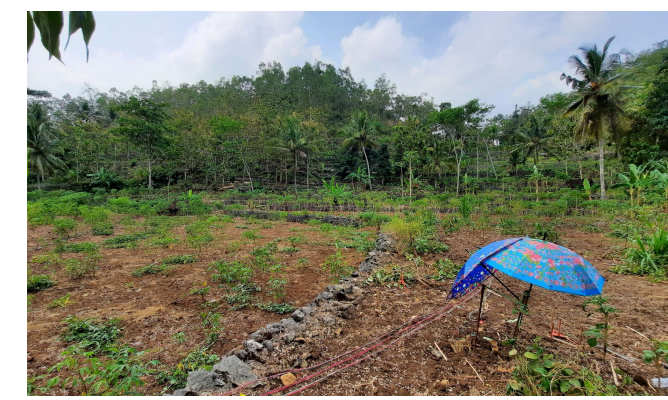

Gambar 8. Kondisi lintasan Dipole-2 berada pada area doline

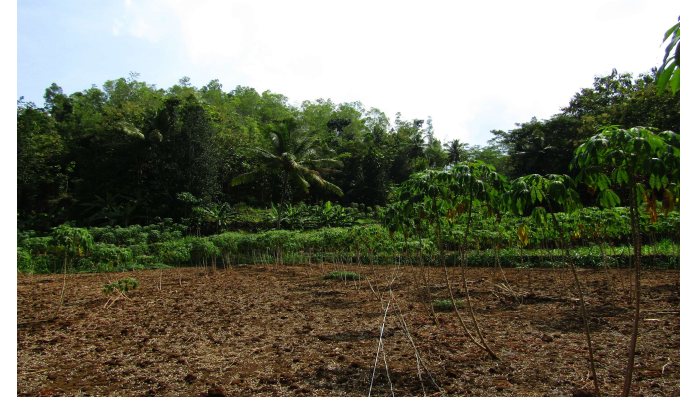

Gambar 9. Kondisi lintasan Dipole-1 berada pada area doline

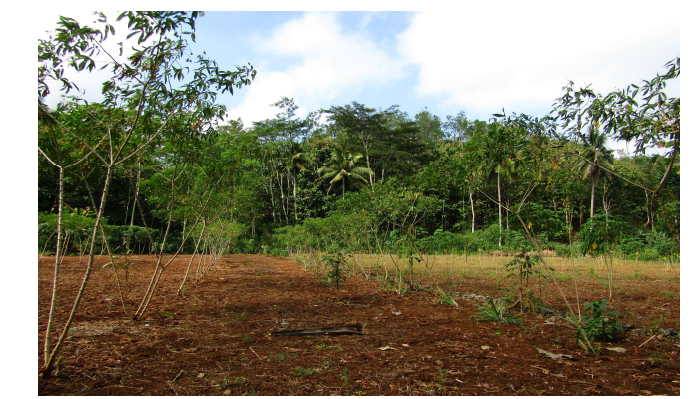

Gambar 10. Kondisi lintasan Dipole-3 berada pada area doline

2. Tahapan Akuisisi Data

Akuisisi data dilakukan pada tanggal 24 Mei 2021, 26 Mei 2021, dan 27 Mei 2021. Waktu pelaksanaan akuisisi dilakukan pada saat musim kemarau dimana kondisi lapangan sangat kering. Akuisisi data dilakukan menggunakan metode geolistrik resistivitas 2D dengan konfigurasi DipoleDipole pada tiga lokasi berbeda dimana panjang setiap lintasan yaitu 230 meter dan spasi elektroda 10 meter. Jumlah elektroda yang digunakan sebanyak 24 elektroda dengan pengaturan konfigurasi terdapat pada kabel rol yang berperan sebagai elektroda potensial (P1 dan P2) serta elektroda arus (C1 dan C2). Data hasil pengukuran di lapangan yaitu berupa besar arus listrik (I) yang dialirkan ke bumi, nilai potensial sebelum diinjeksikan arus (SP), serta beda potensial (V) yang terukur dari hasil injeksi arus. Setelah selisih beda potensial $(\Delta \mathrm{V})$ dan besar arus listrik (I) diperoleh, kemudian dilakukan quality control untuk memvalidasi nilai Rhoapp pada data $\mathrm{n}=1$ di lapangan dengan cara melihat trend data yang dihasilkan dari pengukuran. Visualisasi pseudosection konfigurasi tersebut dapat ditunjukkan pada gambar 11 sebagai berikut.

\section{Tahapan Pengolahan Data}

Tahapan pengolahan data dimulai dengan melakukan perhitungan nilai resistivitas semu dari data yang didapatkan. Data yang digunakan sebagai data input yaitu beda potensial $(\Delta \mathrm{V})$, besar arus listrik (I), spasi elektroda (a), datum point, dan level data $\mathrm{n}$. Pengolahan data dilakukan dengan menghitung nilai resistansi ( $R$ ) terlebih dahulu, kemudian menghitung faktor geometri (k) masing-masing konfigurasi, dan dilanjutkan dengan perhitungan Rhoapp (resistivitas semu) dengan persamaan 2. Hasil pengolahan data dimasukkan ke dalam notepad untuk menyimpan data berbentuk .dat sebagai input software RES2DINV. Pengolahan data pada RES2DINV dilakukan dengan analisis bad datum terlebih dahulu untuk mengurangi data di luar trend quality control yang dapat menyebabkan nilai error menjadi tinggi. Setelah itu kemudian dilakukan inversi data. Inversi 2D yang digunakan adalah combined-inversion dengan penentuan parameter inversi berasal dari damping factor. 


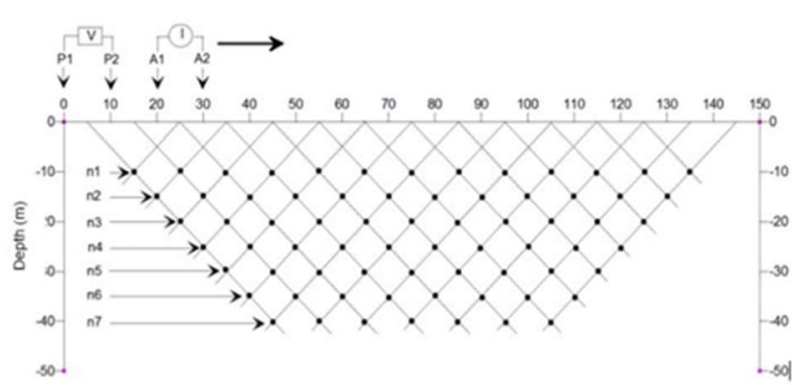

Gambar 11. Pseudosection konfigurasi Dipole-Dipole (Octova dan Yulhendra, 2017)

\section{HASIL DAN PEMBAHASAN}

Berdasarkan referensi pada Tabel 2, interpretasi nilai resistivitas pada masing-masing lintasan di lokasi penelitian dapat dijelaskan sebagai berikut.

Tabel 3. Distribusi nilai resistivitas pada lintasan Dipole-1

\begin{tabular}{ccc}
\hline Jenis Anomali & Nilai Resistivitas & Kedalaman \\
\hline $\begin{array}{c}\text { Top soil } \\
\text { Batuan karbonat } \\
\text { terumbu }\end{array}$ & $1,26-18,2 \Omega \cdot \mathrm{m}$ & $12 \mathrm{~m}$ \\
Goa penuh air & $123-387,2 \Omega \cdot \mathrm{m}$ & $35-50 \mathrm{~m}$ \\
\hline Lintasan Dipole-1 (Gambar & 12, & Tabel 3)
\end{tabular}

menghasilkan kedalaman mencapai 50,4 meter pada elevasi 280 - 330 mdpl. Anomali top soil ditemukan pada jarak 15 - 140 meter dengan ketebalan sekitar 12 meter dengan nilai resistivitas yaitu 1,26 - 18,2

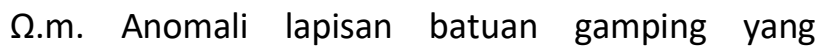
berbentuk rongga (batuan karbonat terumbu) ditemukan pada jarak 50 - 90 meter dan 190 - 215 meter, serta lapisan batuan gamping yang memanjang pada kedalaman sekitar 35 - 50 meter dengan nilai resistivitas yang tinggi yaitu 123 - 387,2 $\Omega$.m. Indikasi anomali sungai bawah permukaan (goa penuh air) yang dihasilkan berada pada kisaran 1,26

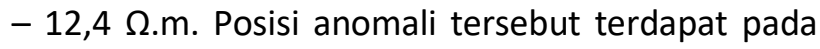
kedalaman 9,25 - 35 meter (elevasi 300 - 325 mdpl) yang berada pada jarak 75 - 120 meter, jarak 140 170 meter dengan kedalaman 5-14,5 meter (elevasi 313 - 325 mdpl), serta pada jarak 160 - 188 meter dengan kedalaman 12 - 27 meter (elevasi $302-318$ mdpl). Selain itu indikasi anomali aliran atau saluran sisa sungai purba ditemukan pada jarak 42 - 49 meter serta 53 - 57 meter yang ditandai oleh garis putus-putus berwarna putih. Indikasi aliran atau saluran sisa sungai purba ini terbentuk dan melarutkan batuan karbonat di sekitarnya pada masa lampu yang kemudian terisi oleh endapan sedimen muda berupa tanah (Sadikin, 2013).

Tabel 4. Distribusi nilai resistivitas pada lintasan Dipole-2

\begin{tabular}{ccc}
\hline Jenis Anomali & Nilai Resistivitas & Kedalaman \\
\hline Top soil & $1,26-18,2 \Omega \cdot \mathrm{m}$ & $12 \mathrm{~m}$ \\
Batuan karbonat & $12,5-387,2 \Omega \cdot \mathrm{m}$ & $9,25-50,4$ \\
terumbu & $\mathrm{m}$ \\
Goa penuh air & $1,26-12,4 \Omega . \mathrm{m}$ & $9,25-35 \mathrm{~m}$ \\
\hline
\end{tabular}

Lintasan Dipole-2 (Gambar 13, Tabel 4) menghasilkan kedalaman mencapai 50,4 meter pada elevasi 240 - 290 mdpl. Anomali top soil ditemukan pada jarak 15 - 50 meter serta 92 - 167 meter dengan ketebalan sekitar 12 meter dengan nilai resistivitas yaitu 1,26 - 18,2 $\Omega$.m. Anomali lapisan batuan gamping berbentuk rongga (batuan karbonat terumbu) ditemukan pada jarak 50 - 100 meter dan 185 - 215 meter dengan nilai resistivitas pada kisaran 12,5 - 263,9 $\Omega . m$, serta pada jarak 80 - 170 meter dengan kedalaman 9,25 - 50,4 meter memiliki nilai resistivitas yang tinggi yaitu 57,4 - 387,2 $\Omega . m$. Indikasi anomali sungai bawah permukaan (goa penuh air) yang dihasilkan berada pada kisaran 1,26 - 12,4 Л.m. Posisi anomali tersebut terdapat pada kedalaman 9,25 - 29,4 meter (elevasi 255 - 275 mdpl) yang berada pada jarak 50 - 100 meter, jarak 152 - 180 meter dengan kedalaman 16 - 35 meter (255 - 275 mdpl). Selain itu indikasi anomali aliran atau saluran sisa sungai purba ditemukan pada jarak 173 - 189 meter serta pada jarak 200 - 215 meter yang ditandai oleh garis putus-putus berwarna putih.

Lintasan Dipole-3 (Gambar 14, abel 5) menghasilkan kedalaman mencapai 58,9 meter dan berada pada elevasi $265-325 \mathrm{mdpl}$. Anomali top soil ditemukan pada jarak 15 - 60 meter, 110 - 138 meter, serta 152 - 175 meter dengan ketebalan sekitar 12 meter dengan nilai resistivitas yaitu 1,2618,2 Л.m. Anomali lapisan batuan gamping berbentuk rongga (batuan karbonat terumbu) ditemukan pada jarak 60-120 meter serta 120-165 meter dengan nilai resistivitas pada kisaran 12,5 387,2 $\Omega . m$, serta pada kedalaman 5 - 58,9 meter sepanjang jarak 50 - 200 meter dengan nilai resistivitas 57,4 - 387,2 $\Omega$.m. Indikasi anomali sungai bawah permukaan (goa penuh air) yang dihasilkan

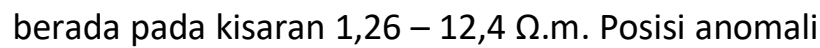




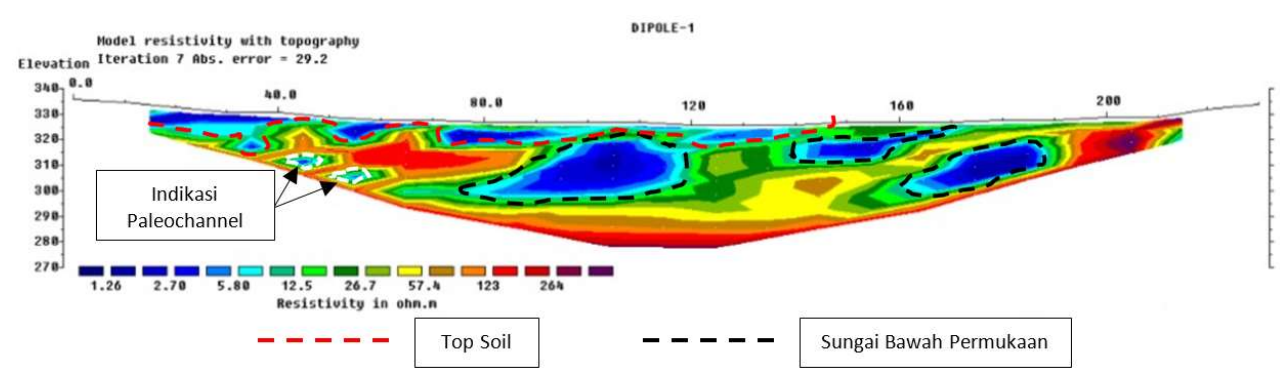

Gambar 11. Penampang resistivitas 2D lintasan Dipole-1

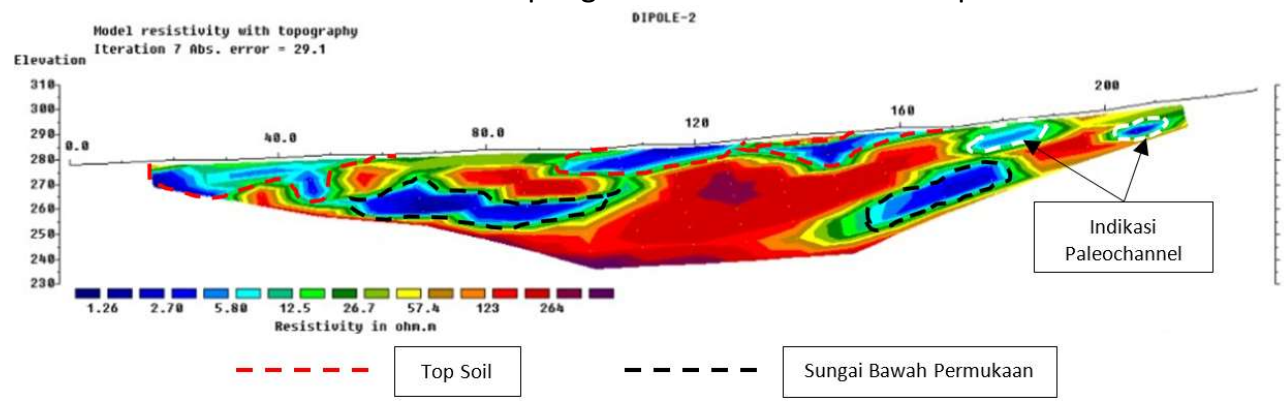

Gambar 12. Penampang resistivitas 2D lintasan Dipole-2

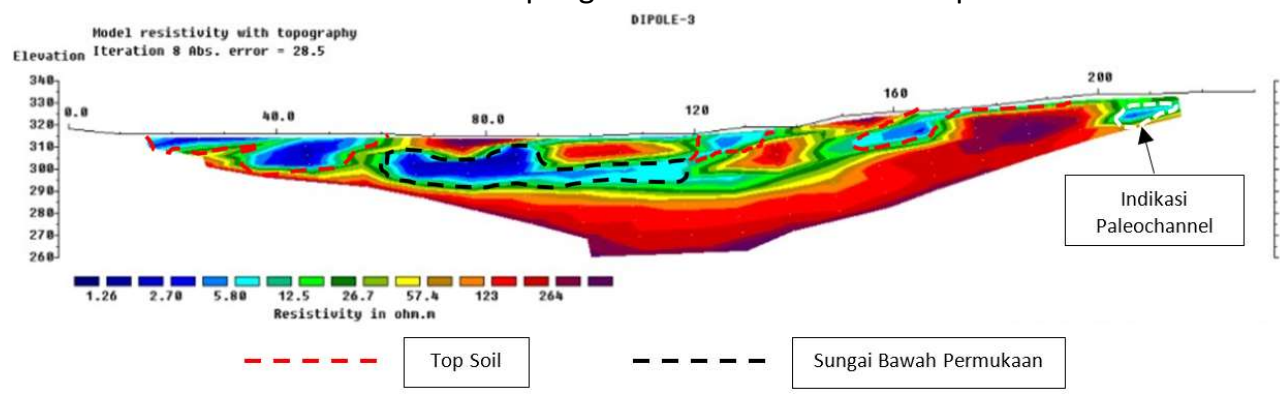

Gambar 13. Penampang resistivitas 2D lintasan Dipole-3

tersebut terdapat pada kedalaman 5 - 23,6 meter (elevasi 295 - 315 mdpl) yang berada pada jarak 60 120 meter. Selain itu indikasi anomali aliran atau saluran sisa sungai purba ditemukan pula anomali pada jarak 202 - 212 meter yang ditandai oleh garis putus-putus berwarna putih.

Tabel 5. Distribusi nilai resistivitas pada lintasan Dipole-3

\begin{tabular}{ccc}
\hline Jenis Anomali & Nilai Resistivitas & Kedalaman \\
\hline Top soil & $1,26-18,2 \Omega \cdot \mathrm{m}$ & $12 \mathrm{~m}$ \\
Batuan karbonat & $12,5-387,2 \Omega \cdot \mathrm{m}$ & $5-58,9 \mathrm{~m}$ \\
terumbu & $1,26-12,4 \Omega . \mathrm{m}$ & $5-23,6 \mathrm{~m}$ \\
\hline Goa penuh air &
\end{tabular}

Hasil interpretasi penampang resistivitas menunjukkan keberadaan anomali sungai bawah permukaan yang teridentifikasi pada kedalaman 5 35 meter dengan nilai resistivitas berkisar antara 1,26 - 12,4 $\Omega . m$. Anomali resistivitas rendah ini memiliki bentuk menyerupai rongga yang diindikasikan sebagai goa penuh air. Nilai resistivitas yang rendah tersebut dihasilkan karena adanya asosiasi dengan air tanah yang terdapat di bawah permukaan. Namun karena pada saat pengukuran kondisi cuaca sedang memasuki musim kemarau, anomali yang dihasilkan cenderung memiliki dimensi yang kecil. Sementara itu, anomali resistivitas tinggi yang teridentifikasi sepanjang penampang memiliki bentuk berupa rongga atau perlapisan. Nilai resistivitas yang dihasilkan termasuk ke dalam kategori litologi batuan karbonat terumbu karena berada pada kisaran 12,5 - 387,2 $\Omega$.m. Oleh karena itu anomali resistivitas tinggi pada daerah penelitian tidak berasosiasi baik dengan goa setengah kosong atau goa kosong karena penampang yang dihasilkan tidak menunjukkan nilai resistivitas dari kedua anomali tersebut.

Anomali rongga yang terbentuk pada daerah penelitian ini dipengaruhi oleh sistem perkembangan sungai bawah permukaan yang termasuk ke dalam zona vadose (Bahri dkk., 2019)(Bahri dkk., 2019). Dalam hal ini, air yang berasal dari permukaan terinfiltrasi secara vertikal ke 
dalam tanah melalui luweng atau ponor (lubang atau saluran masuknya air yang berasal dari permukaan ke dalam batuan). Ketika air memasuki zona jenuh air, maka pergerakannya berubah ke arah horizontal mengikuti celah yang terdapat pada batuan baik berupa kekar, bidang perlapisan, dan sebagainya. Pergerakan air ini mengakibatkan batugamping yang dilalui oleh air mengalami pelarutan dan tererosi sehingga menyebabkan celah-celah tersebut perlahan semakin melebar hingga membentuk rongga. Rongga-rongga tersebut kemudian membentuk konduit baik berupa saluran sungai bawah permukaan atau kantung air. Anomali yang membentuk konduit ini selanjutnya dapat berkembang menjadi saluran sungai bawah permukaan.

Sementara itu terdapat indikasi saluran sungai purba (paleochannel) yang ditunjukkan oleh anomali dengan nilai resistivitas sangat rendah dan berbentuk menyerupai rongga yang berukuran kecil. Adanya indikasi saluran sisa sungai purba atau paleochannel pada penampang konfigurasi DipoleDipole menunjukkan sisa dari alur sungai yang pernah terbentuk dari batuan gamping pada masa lampau. Sisa alur sungai ini kemudian terisi oleh endapan sedimen berusia muda yang berupa tanah dan menutupi batuan gamping tersebut (Sadikin, 2013). Hal tersebut terjadi karena adanya proses pelarutan air yang menyebabkan proses karstifikasi sehingga air menggerus lapisan batuan gamping tersebut dan membentuk rongga sebelum akhirnya terisi oleh endapan sedimen muda (tanah) (Tobing, 2020). Adanya anomali dengan resistivitas rendah tersebut mengindikasikan adanya gejala pelarutan yang masih bekerja sehingga aliran air yang terdapat di dalamnya diduga dalam keadaan aktif walaupun dalam jumlah yang sangat sangat sedikit.

\section{PENUTUP}

\section{Simpulan}

Berdasarkan hasil pengolahan dan interpretasi data resistivitas 2D di daerah penelitian, didapatkan kesimpulan sebagai berikut.

1. Anomali sungai bawah permukaan di Desa Gedompol, Kecamatan Donorojo, Kabupaten
Pacitan teridentifikasi pada penampang 2D di kedalaman $5-35$ meter dengan nilai resistivitas berkisar antara 1,26 - 12,4 $\Omega . m$ dan terindikasi sebagai goa penuh air.

2. Anomali ini berbentuk rongga akibat pengaruh sistem perkembangan sungai bawah permukaan yang termasuk ke dalam zona vadose. Pada zona ini air yang berasal dari permukaan terinfiltrasi secara vertikal ke dalam tanah melalui luweng atau ponor dan pergerakannya berubah mengikuti celah yang mengakibatkan batugamping yang dilalui oleh air mengalami erosi sehingga celah-celah yang terbentuk semakin melebar hingga membentuk rongga. Rongga ini yang kemudian terisi oleh air dan berkembang menjadi saluran sungai bawah permukaan atau kantung air.

\section{Saran}

Saran yang dapat disampaikan dari penelitian ini untuk penelitian selanjutnya adalah :

1. Pengukuran dilakukan dengan menggunakan spasi elektroda yang lebih kecil dengan lintasan pengukuran yang lebih panjang untuk mendapatkan penetrasi yang lebih dalam.

2. Perlunya dilakukan pengukuran dengan metode VLF untuk dapat mengetahui nilai konduktivitas yang terukur di lokasi penelitian, sehingga dapat dilakukan korelasi dengan data resistivitas 2D.

3. Rekomendasi pengeboran dapat dilakukan pada lintasan Dipole-1 karena terdapat anomali rongga penuh air yang memiliki dimensi cukup besar.

\section{Ucapan Terima Kasih}

Penulis mengucapkan terimakasih kepada Departemen Teknik Geofisika ITS yang telah memberikan izin kepada penulis dan menyediakan fasilitas untuk melakukan penelitian di kawasan karst Pacitan.

\section{DAFTAR PUSTAKA}

Adji, T. dan Haryono, E. (2004), Geomorfologi dan Hidrologi Karst.

Aliyan, S., Bahri, A., Widodo, A. dan Utama, W. (2020), Remote Sensing Data Integration of Landsat 8 and SRTM for Geomorphological Characteristics Identification in, Vol.10, hal. 212-218. http://doi.org/10.18517/ijaseit.10.1.6751.

Andriyani, S., Ramelan, A.H. dan Sutarno (2010), "Metode Geolistrik Imaging Konfigurasi Dipole-Dipole Digunakan untuk Penelusuran Sistem Sungai Bawah 
Tanah pada Kawasan Karst di Pacitan Jawa Timur", Jurnal EKOSAINS, Vol.II, No.2, hal. 46-54.

Bahri, A., Abdullah, M., Aliyan, S., Purwanto, M., Widodo, A., Hilyah, A., Fajar, M.H.M., Hardyani, P., Wicaksono, S., Alita, E., Rahmat, M. dan Nurfitriana, I. (2021), "Identification of underground river with microtremor method in Dersono karst area, Pacitan", IOP Conference Series: Earth and Environmental Science, Vol.649, hal. 012001. http://doi.org/10.1088/1755-1315/649/1/012001.

Bahri, A., Hardyani, P., Utama, W., Hilyah, A., Purwanto, M. dan Fajar, M.H.M. (2019), "Controlling factors of underground river system of karst region in Pacitan Regency, East Java", IOP Conference Series: Earth and Environmental Science, Vol.311, hal. 012033. http://doi.org/10.1088/1755-1315/311/1/012033.

Bemmelen, V. (1949), The General Geology of Indonesia and Adjacent Archipelagoes Vol IA.

Chemistra, P., Bahri, A., Utama, W. dan Widodo, A. (2018), Characterization of Microtremor for The Identification of Subsurface Rivers at Kedung Banteng, Pacitan, Indonesia. http://doi.org/10.3997/2214-4609.201800395.

Ebraheem, A., Sherif, M., Akram, S. dan Shetty, A. (2012), "A Geoelectrical and Hydrogeological Study for the Assessment of Groundwater Resources in Wadi Al Bih", Environmental earth sciences, Vol.67, hal. 845857. http://doi.org/10.1007/s12665-012-1527-0.

Ford, D. dan Williams, P.D. (2013), Google-Books-ID: whgNDVXFiqYC, Karst Hydrogeology and Geomorphology, John Wiley \& Sons.

Haryono, E. (2011), Introduction to Gunungsewu Karst: Asian Trans-Disciplinary Karst Conference Field Guide. http://doi.org/10.31227/osf.io/7w2sh.

Kuswanto, A. (2005), "Aplikasi Metoda RES-2D Untuk Eksplorasi Air Bawah Tanah Di Daerah Karst", Jurnal Air Indonesia, Vol.1, No.2. http://doi.org/10.29122/jai.v1i2.2349.

Loke, M.H. (2001), Tutorial: 2-D and 3-D Electrical Imaging Surveys, Geotomo Software, Malaysia.

Naufaldi, F. (2018), Pemetaan Pola Aliran Sungai Bawah Permukaan Menggunakan Metode Resistivitas 2D Di Daerah Kedung Banteng, Pacitan, Jawa Timur, Undergraduate, Institut Teknologi Sepuluh Nopember. Diambil dari https://repository.its.ac.id/50845/.

Octova, A. dan Yulhendra, D. (2017), "Iron ore deposits model using geoelectrical resistivity method with dipole-dipole array", MATEC Web of Conferences,
Vol.101.

http://doi.org/10.1051/matecconf/201710104017.

Prameswari, F.W., Bahri, A.S. dan Parnadi, W. (2012), "Analisa Resistivitas Batuan dengan Menggunakan Parameter Dar Zarrouk dan Konsep Anisotropi", Jurnal Sains dan Seni ITS, Vol.1, No.1, hal. B15-B20. http://doi.org/10.12962/j23373520.v1i1.232.

Putra, D.P.E. dan Hermawan, O.R. (2016), "The Effectiveness of Wenner-Schlumberger and DipoleDipole Array of 2D Geoelectrical Survey to Detect The Occurring of Groundwater in the Gunung Kidul Karst Aquifer System, Yogyakarta, Indonesia", Journal of Applied Geology, Vol.1, No.2, hal. 71-81. http://doi.org/10.22146/jag.26963.

Reynolds, J.M. (2011), Google-Books-ID: kMnHYMgMzVQC, An Introduction to Applied and Environmental Geophysics, John Wiley \& Sons, New Jersey.

Sadikin, A. (2013), "Pemetaan Alur Sungai Bawah Permukaan dengan Resistivitas Elektrik di Daerah Gunungkidul", JURNAL SUMBER DAYA AIR, Vol.9, No.1, hal. 13-24. http://doi.org/10.32679/jsda.v9i1.360.

Samodra, H. (2003), Nilai Strategis Kawasan Kars di Indonesia dan Usaha Pengelolaannya secara Berkelanjutan.

Samodra, H., Gafoer, S. dan Tjokrosapoetro, S. (1992), Peta Geologi Lembar Pacitan, Jawa,.

Surono, Toha, B. dan Sudarno, I. (1992), Peta Geologi Lembar Surakarta - Giritontro, Jawa,.

Telford, W.M., Geldart, L.P. dan Sheriff, R.E. (1990), Applied Geophysics (Second Edition).

Tobing, K.C. (2020), Aplikasi Metode Combined Inversion pada Data Geolistrik Resistivitas 2D Konfigurasi Wenner-Schlumberger untuk Identifikasi Sungai Bawah Permukaan Kawasan Karst, Pacitan, Undergraduate, Institut Teknologi Sepuluh Nopember. Diambil dari https://repository.its.ac.id/78800/.

Yuspancana, B.D., Purwanto, M.S., Bahri, A.S. dan Utama, W. (2019), "Integrasi Data Resistivitas 2D Dengan Parameter Fisis Dan Mekanis Tanah Untuk Evaluasi Daya Dukung Tanah (Studi Kasus: Ruas Jalan Kawasan Jiipe, Manyar, Gresik)", Jurnal Geosaintek, Vol.5, No.2, hal. 85-90. http://doi.org/10.12962/j25023659.v5i2.5403. 